\title{
Non-Contributory Benefits, Pension Re-Reforms and the Social Protection of Older Women in Latin America
}

\author{
Camila Arza \\ Consejo Nacional de Investigaciones Científicas y Técnicas, Centro Interdisciplinario para el Estudio de Políticas \\ Públicas, Buenos Aires, Argentina. \\ E-mail: carza@ciepp.org.ar
}

Gender inequalities are a key issue for most pension systems in Latin America. Contributory pension schemes that link benefit entitlements to work and earnings tend to reflect in the benefits they offer the gender gaps that prevail in the labour market. This deepened with the implementation of individual private accounts as part of structural pension reforms in a number of countries. This article evaluates how recent pension policies, including measures geared to coverage expansion and so-called pension 're-reforms', have addressed gender gaps in pensions in four Latin American countries. It shows that the expansion of non-contributory pensions and a greater emphasis on redistribution are important for the protection of older women in a context of gendered labour markets and the unequal distribution of paid and unpaid work between women and men. Looking at the cases of Argentina, Bolivia, Brazil and Chile, the article identifies progress but also the persistence of gender gaps in pensions and emphasises the need for further measures to promote adequate social protection for older women.

Keywords: social security, pension system, gender equality, coverage, non-contributory pensions, old age.

\section{Introduction}

Gender gaps are a common problem for pension systems around the world. As a large body of research has shown, gendered labour markets often make contributory pension systems unable to provide equal levels of protection to older women and men. Until recently, gender gaps in pensions were little considered in Latin America, and were not a major component of the debates that took place during the structural pension reforms of the 1980s and 1990s. Some years after individual pension accounts were implemented, however, coverage gaps and gender inequality increasingly became an issue in policy debates and reform agendas.

Recently a number of countries in Latin America implemented new pension reforms (so-called 're-reforms'), including measures to expand basic protection for older adults who previously lacked access to a pension (Arza, 2012a; Hohnerlein, 2012; Kritzer et al., 2011; Mesa-Lago, 2012; Mesa-Lago, 2009; Mesa-Lago and Ossio Bustillos, 2012). While coverage expansion measures had already had a positive impact on women's access to pensions, some reforms went further, embracing gender equality as an objective. 
This article evaluates the experiences of four Latin American countries (Argentina, Bolivia, Brazil and Chile) focusing on recent measures that have addressed gender gaps in old age protection in one way or another. It first describes how gender differences in labour market participation and earnings usually compromise women's pension entitlements. Second, it reviews pension policies in four countries and studies how recent coverage expansion programs and pension 're-reforms' have addressed gender gaps in pensions. The analysis highlights the role of the redistributive components in the pension system for the protection of older women, showing progress but also persisting inequalities. Finally, the conclusion discusses some of the obstacles and pending challenges for genderequitable pension systems in Latin America, and emphasises the need for further measures to achieve gender equality in old age, which also involves enhancing gender equality over the lifecourse.

\section{The reasons for gender gaps in pensions}

Across countries and regions, labour markets are gender biased. Women tend to participate at lower rates in the labour market, earn less, have more breaks in their careers and a higher rate of part-time work than men. On average, women dedicate a substantial amount of their working time to perform unpaid household work and to take care of children and other family members. Thus, when pension entitlements are linked to paid work and contributory history, older women are less likely to receive an adequate benefit than men. Indeed, many receive no pension benefit at all.

Informal employment is another long-standing obstacle to reaching full pension coverage for both men and women. In most Latin American countries, a high percentage of the employed population works in the informal sector and has no contributory pension rights. Indeed, in many Latin American countries, only a minority of older adults receive a contributory pension. In the case of women, this problem is intensified by the combined impact of high informality and low labour market participation rates. As a result, older women are on average less likely than men to receive a contributory pension benefit.

The family structure is also relevant to women's old-age protection. Pension systems based on a 'male breadwinner' family model have been traditionally conceived to protect women as economically dependent, under the assumption that men provide the household with income (earnings or pensions) and women obtain a derived benefit ('the widows pension') in case the husband dies. Under that model, widow pensions are a sort of insurance against the male breadwinner's death. Indeed, widow benefits continue to be an essential component in the social protection of older women in many countries. But as marriage rates drop and divorce rates increase, the protection of women through derived benefits is becoming less and less certain. Furthermore, these derived pension rights do not even provide all married women with protection. In Latin American countries, many women have no right to a derived pension if they become widowed because their husbands work in the informal sector with no contributory pension rights.

Specific features of pension design also matter. Indeed, the ability of pension systems to protect women depends on the rules governing access to benefits and benefit levels (Arza, 2012c, 2015; Frericks and Maier, 2008; Gilbert, 2006; Ginn, 2008). Eligibility rules and benefit formulas are key components of pension design. Both are operative in defining 
whether and how work and earnings' histories influence pension benefit levels. Women tend to benefit particularly from pension design geared to redistribution, with components such as flat-rate pensions, minimum pensions and non-contributory pensions. In contrast, pension systems that require lengthy contribution records, and closely associate benefits to individual earnings (or to individual savings, as individual accounts), tend to reflect the differences in working and earnings trajectories of women and men in the benefits they get. This generally means lower pension coverage and lower benefits for women. In some cases, women's earlier retirement and higher life expectancy further reduces their benefits relative to men. ${ }^{1}$

\section{Addressing gender gaps: basic pensions and 're-reforms' in Latin America}

Starting with Chile in 1981, a number of Latin American countries implemented structural pension reforms that partly or fully replaced public earnings-related systems with fully funded individual accounts (e.g. Barrientos, 1998; Brooks, 2009; Madrid, 2003; Mesa-Lago, 2006). Although the specific design features varied substantially from country to country, reforms brought a new mechanism for benefit calculation, one based on the value of the funds that each individual would accumulate over the course of a working life (contributions, plus returns, minus administrative costs) and life expectancy. In other countries like Brazil, which did not go through the same structural reforms, a number of measures implemented since the 1990 s were also oriented to tighten benefits and contributions, with the aim of containing rising pension costs, and to encourage the development of complementary and voluntary individual pensions.

From roughly about year 2000, several governments in Latin America started to pay more attention to the limitations of existing pension systems specifically in terms of their ability to provide universal and adequate protection. In some countries that had undertaken structural pension reforms in the past (such as Argentina, Bolivia and Chile), new policies geared to dealing with the drawbacks of existing individual account-based systems were introduced. These reforms went all the way from regulatory adjustments to the complete dismantlement of those systems (as in Argentina) (Calvo et al., 2010; Kritzer et al., 2011; Mesa Lago, 2009).

Policies for coverage expansion were among the most important instruments to improve the protection of older adults in lower income groups and to reduce gender gaps in access to a pension. Some recent reforms also incorporated specific measures for gender equality, intended to (at least partly) compensate for the costs that the unequal distribution of paid and unpaid work between men and women can have for women's old age protection. Chile is a case in point. Other countries such as Brazil, where the social security system continued to be public and pay-as-yougo (PAYG), the improvements in women's coverage started earlier in the context of democratisation and the expansion of social rights embedded in the new Constitution of 1988.

In the four countries studied here, basic pensions of various kinds have been crucial to the protection of older women and to reducing gender gaps in pension coverage. Recent policies have clearly not solved all gender inequalities in old age. Their achievements as well as shortcomings bring important lessons regarding the opportunities and constraints for gender equitable pension policies. ${ }^{2}$ 


\section{Expansion of coverage and minimum pensions: Argentina and Brazil}

While in recent decades Argentina and Brazil took rather different pension policy trajectories (Argentina partly privatised the pension system in 1993/4 while Brazil did not), in both cases the creation of pension benefit options with no or limited contributory requirements and the establishment of minimum pensions were important policies from a gender equality perspective. In both countries, the pension system has been able to reach a relatively high share of older adults and reduce gender gaps in pension coverage.

In Brazil, the Constitution of 1988 laid the foundation for a comprehensive social security system (Beltrão et al., 2005; Fagnani and Tonelli Vaz, 2013). The protection of older adults improved as coverage increased and the minimum pension (for both contributory and non-contributory benefits) was set at the value of a monthly minimum wage. Between 1990 and 2014, women's old age pension coverage rose from 74.3 to 81.4 per cent at the national level and from 72.7 to 89.7 per cent in rural areas (IDB, 2015). Most of that increase was produced in the period 1990-2001, as the new benefits emerging from the Constitution of 1988 were implemented.

The Brazilian pension system was not privatised as part of the structural economic reforms as others in the region. However, a number of reforms have been geared to tightening eligibility due to concerns over financial sustainability (Rocha da Silva and Schwarzer, 2003; Schwarzer and Ferreira de Santana, 2013; Matijascic and Kay, 2014). There was also an expansion of complementary pension schemes of funded occupational and individual accounts (closed and open pension funds), but no replacement of public with private pensions as in other countries (Antía and Provasi Lanzara, 2011).

In Brazil, the pressures for public pension retrenchment (which also existed) could not undo the achievements made over the demoncratisation process and pursuant the mandates of the Constitution of 1988. Among these achievements are current programs of rural and social assistance pensions, two central components of social security in Brazil. The social assistance pension (BPC - Benefício de Prestação Continuada) was created in 1993 (implemented in 1996), replacing a more limited benefit existing before (RMV - Renda Mensal Vitalícia). The BPC offers a benefit for older adults and disabled people who have no other pension, and requires no record of contributions. However, access to benefits is means-tested and only older adults in households with per capita income below a quarter of the monthly minimum wage are eligible. Thus, benefits are only oriented to families with a very low income.

On the other hand, rural workers in the family economy, subsistence fishermen and gold miners, are only required to give proof of work (not contribution) to receive pension benefits. Pursuant the Constitution of 1988, women's access to these benefits increased. Under the previous system, rural pension benefits were given only to the head of household, a policy that effectively excluded most women. The new rules extended benefits to other household members (whether heads of household or not), thus granting many women the right to receive a pension (Rocha da Silva and Schwarzer, 2003; Alásia de Heredia and Pezza Cintrão, 2006). Rural pensions contributed to high coverage and to reduce gender inequalities among older persons in rural areas, where women's pension coverage is now very high. Since the benefit is flat-rate, earnings inequalities are reduced after retirement: it was estimated that women in rural areas receive 35 per cent of men's earnings while active, and up to 88 per cent of men's income after retirement (Lavinas, 2012: 75). 
While both social assistance and rural pensions - which are flat-rate and require no past contribution - avoid gender differences, this is not the case with other components of the social security system in Brazil. Indeed, one indicator that reflects how working trajectories and pension eligibility rules influence women's and men's access to old age protection is the distribution of benefits by type. In old-age rural pensions and old-age social assistance pensions, women represent 60.6 and 58.2 per cent of all beneficiaries, respectively, which suggests gender parity considering the higher life expectancy of women. Women are 84.3 per cent of all beneficiaries of derived pensions (pensão por morte) and 65.5 per cent of beneficiaries of old-age urban pensions for which 15 years of contribution are required. In contrast, women are only 30 per cent of beneficiaries of 'contributing time' pensions (aposentadoria tempo de contribuição), for which a longer contribution period is required. ${ }^{3}$ This is a 'typically male' benefit (Rocha da Silva and Schwarzer, 2003: 102-3). In other words, women are less likely than men to get benefits that require lengthy contribution records, which are, at the same time, the ones that offer higher benefit amounts on average. ${ }^{4}$

So while women's pension coverage is high in Brazil, gender differences continue to be reflected both in the types of benefits each one has access to, as well as in average benefit values: it is estimated that the average contributory pension benefit for women (excluding derived benefits) is about 69 per cent the benefit for men. ${ }^{5}$ Clearly, the gender gap in benefits would be higher without the minimum pension, equal to the monthly minimum wage, which has risen in real terms in the last few years. Currently, over two-thirds of beneficiaries - including rural and social assistance pensioners - receive the minimum pension, and in rural areas almost all pensioners receive the minimum pension (Schwarzer and Ferreira de Santana, 2013: 129; MPS, 2013). This benefit floor has been found to have a substantial impact on the reduction of poverty among older adults (Matijascic and Kay, 2014: 76). It is particularly important for women: for instance, it is estimated that 67 per cent of all new social security pensions (for old age, contributing time and widowhood) that were granted to women in year 2013 were minimum pensions. ${ }^{6}$

Unlike Brazil, Argentina undertook a structural pension reform in 1993/4, establishing a mixed public-private system that included mandatory fully funded individual accounts. About fifteen years later, in 2008/9, a subsequent reform restored a fully public PAYG system (Arza, 2012a). As in other countries, the limitations of private pensions were many, including high fiscal costs for the transition from a PAYG to a fully funded system, high administrative fees and low coverage (Arza, 2008; Goldberg and Lo Vuolo, 2006; on pensions and gender over that period in Argentina, see Rofman and Grushka, 2003). Individual accounts meant a closer association between contributions and benefits. As a result, gender differences in paid work, earnings, retirement age and life expectancy were bound to be reflected in benefit entitlements. In addition, a requirement of thirty years of contributions made it difficult for women (or anyone without a long trajectory of formal employment) to obtain a benefit from the public system. By 2005, the pension coverage rate for women aged sixty-five and over was 66.4 per cent, compared to 72.8 per cent in 1995 (IDB, 2015).

Roughly a decade after the structural pension reform, the system was modified in several ways. The most far-reaching reform, enacted in 2008, did away with individual accounts to return to a fully public PAYG system. Unlike the cases of Bolivia and Chile discussed below, in Argentina gender equality was not presented as a guiding principle for the pension 're-reform', and no specific measures for gender equality were included 
in those new rules. Some of the outcomes of the reform, however, did have gender implications. In the new system, for instance, the higher life expectancy for women does not affect their pensions any longer, since longevity is not included in the benefit formula.

One of the most important recent measures for women's access to pensions was the so-called Pension Moratorium. It was a far-reaching program geared to providing older women and men who could not meet the contributory requirement with the opportunity to obtain a pension benefit (Arza, 2012b; Bertranou et al., 2011). In June 2012, 2.6 million pension benefits paid had been obtained pursuant to this program, which represents almost half of all pensions paid at the time (MTEySS, 2012: 29; see also Rofman, 2013). Most of the beneficiaries of this program were women (ANSES, 2011: 14). Indeed, it is estimated that the coverage rate for women aged sixty-five and over rose from 66.4 to 93.8 per cent between 2005 and 2014 (IDB, 2015).

Despite this success, the program has limitations. In its original version, it applied only to periods of work performed prior to September 1993, which means that access is becoming increasingly restrictive as time passes, and more people have worked informally after that date. A new measure enacted in 2014 in response to this limitation expanded the period until 2003. But this new measure was set to run only for two years and opened up the possibility for a means-test to be applied for eligibility. This raises doubts about the system's ability to maintain high coverage rates in the near future, unless more structural measures are taken.

Regarding benefit levels, the value of the minimum pension is also important in Argentina. Starting in 2002, in a context of high inflation, and given the absence of a regular indexation mechanism at the time, the government started to mandate successive increases in pension benefits, mostly geared to the minimum pension, which rose steadily, though from a very low value. By September 2014, the minimum pension was equal to about to 73 per cent of the monthly minimum wage. ${ }^{7}$ In Argentina, as in Brazil, a large share of pensioners receive the minimum pension (72 per cent in June 2012, last figure available), including most new pensioners entering the Pension Moratorium. ${ }^{8}$ In 2008, an automatic benefit indexation rule was legislated, which was important to keep the real value of benefits in an inflationary context. Regular indexation post-retirement can be particularly valuable for women who normally spend longer periods in retirement and suffer more from benefit depreciation over time in contexts of high inflation.

Both Brazil and Argentina also implemented policies to increase women's affiliation to social security and enhance their future pension rights. One such policy in Brazil was a new measure for lower income women working in the household to join social security with a reduced contribution of 5 per cent of a minimum wage (although they also needed to be included in the government's social assistance registry 'Cadúnico'). By January 2015, more than 410,000 people were affiliated under this category (most of them women) (MPS, 2015). In Argentina, on the other hand, measures to encourage formal employment of domestic workers, including tax deductions for their employers, contributed to an increase in the number of domestic workers affiliated to social security - a sector where women are over-represented and informality prevails (Groisman and Sconfienza, 2013).

But even in countries like Brazil and Argentina, which now enjoy high rates of pension coverage for men and women, gender gaps remain and are unlikely to disappear unless further measures are taken. In Brazil, the old age pension coverage rate for women continues to be below that of men. And in Argentina, where women's coverage rate is now 
higher than men's, this achievement risks evaporating over time unless more structural measures are taken to secure a pension for informal and unpaid workers retiring in the close future. The growing participation of women in the labour market will help in the long run, but gender inequalities persist. The minimum pension in both Brazil and Argentina is important for women as a benefit floor but the average pension for women remains below that of men. Since women live longer and are more likely to become widows and live alone, these lower benefits can compromise their economic security at older ages.

\section{Solidarity pensions and gender-sensitive 're-reforms': Bolivia and Chile}

The 're-reforms' implemented in Bolivia and Chile were different from the one in Argentina. The outcome was not a full revamping but, rather, a recalibration of the existing system with greater state involvement in the provision of basic benefits (see, for example, Mesa-Lago, 2009). In Bolivia, the reform went further and also established that a new public agency would take over the administration of individual accounts. Both reforms were relevant from a gender standpoint. They brought some progress but also left an unfinished task. In Chile, a second round of reforms is currently ongoing and gender inequalities in pensions are once again on the agenda, on the recognition that despite the previous reform, substantial gender gaps remain (Pension Commission, 2015).

Both Chile and Bolivia have a system of individual accounts, first established in Chile in 1981, and later in Bolivia in 1997. Gender gaps in contributory pension coverage and benefit levels are substantial in both countries (Arenas de Mesa and Gana Cornejo, 2003; Arenas de Mesa and Montecinos, 1999; Marco Navarro, 2004; Mesa-Lago, 2004; Bonadona Cossío, 2003). In Bolivia, contributory pension coverage is very low and the gender gap is wide: only 17.2 per cent of women and 26.1 per cent of men over the age of sixty-five receive a contributory pension. In Chile, contributory pension coverage rates are higher but there are gender gaps as well, with only 54.5 per cent of older women compared to 69.2 per cent of men receiving a contributory pension. ${ }^{9}$

Pension 're-reforms' in both Bolivia and Chile were oriented to address some of the limitations of the existing pension systems and, in both cases, there was a concern about gender inequality in pensions. Upon taking office, Chilean President Michelle Bachelet appointed an expert commission to assess the pension system and to make recommendations for reform, including measures to 'eliminate discrimination against women and lower income workers'.$^{10}$ The reform, enacted in 2008, maintained the system based on individual accounts, but created new and better public guarantees to complement the private pension system and introduced specific measures to improve women's pensions (Arenas de Mesa, 2010; Berstein et al., 2009; Délano, 2010; Fajnzylber and Paraje, 2013; Fajnzylber, 2012; Mesa-Lago, 2009). In Bolivia, the pension reform also established gender equality as a policy objective, aiming 'to provide necessary and sufficient mechanisms to close the gaps between women and men in terms of benefits from the Long-Term Social Security System'. ${ }^{11}$

Newly established non-contributory pension schemes were particularly important to provide a benefit floor for uncovered older adults, including many women. In Chile, two types of basic pensions existed before the recent reforms (a minimum guaranteed state pension and a social assistance pension), but they failed to fully cover existing gaps. First, the minimum pension was only available to workers who had contributed for at least twenty years, which, de facto, excluded most women in the informal sector or those 
performing unpaid work in the household. Second, access to the existing social assistance pension (PASIS) was limited by quotas and depended on budget allocations, thus not necessarily covering everyone that needed it (Mesa-Lago, 2009; Pension Commission, 2015).

The Chilean 're-reform' established two types of non-contributory pensions for older adults in the bottom 60 per cent of household income. ${ }^{12}$ First, a Basic Solidarity Pension for old age (PBS - Pensión Básica Solidaria de vejez) was oriented to older adults (aged sixty-five and over) receiving no other pension. The benefit amount is approximately 126 US dollars (£83) per month, and requires no past work or contribution. Second, a Solidarity Pension Complement for old age (APS - Aporte Previsional Solidario de vejez) was geared to enhancing the benefits of older adults with some pension savings but low benefits (below 410 US dollars/£270). The amount of this benefit depends on individual savings. ${ }^{13}$

Unlike other countries, in Bolivia a universal non-contributory pension (Bonosol) was established together with the structural pension reform that introduced individual accounts (Molina, 2006; Müller, 2009; Willmore, 2006). In 2008, Bonosol was replaced by Renta Dignidad, a new universal pension benefit for an amount of about 36 US dollars (£24) per month that everyone receives from age sixty (older adults who have another pension - a minority - get a lower amount). The universal pension was a remarkable achievement in terms of providing the excluded majority with a pension. Notwithstanding, the value of the benefit remains very low, and far lower than that provided by contributory pensions. Indeed, the monthly value of Renta Dignidad is only about one-third of ECLAC's urban poverty line per person in Bolivia. ${ }^{14}$

In 2010, a pension 're-reform' also created a Solidarity Pension for old age (Pensión Solidaria de Vejez). Like the APS in Chile, the Bolivian Solidarity Pension is oriented to enhancing the benefits that workers can obtain from the contributory pension system (Arza, 2012c; Marco Navarro, 2012; Mesa-Lago and Ossio Bustillos, 2012). It is financed by a solidarity fund whose sources include, among others, additional contributions from workers and a newly instituted employer contribution (Laserna, 2013; Marco Navarro, 2012). The benefit varies according to contributory records: workers with a record of at least ten years of contributions are eligible for a minimum benefit of about 81 US dollars (£53) per month, or 116 US dollars ( $£ 76$ ) per month if fifteen years of contributions have been made. Workers with sixteen years of contributions or more receive an earningsrelated supplement, which increases with longer contributory periods, within an earnings threshold. ${ }^{15}$

Non-contributory benefits can be particularly important to women. In Chile women constitute 72.5 per cent of the beneficiaries of the PBSs for old age and 57.9 per cent of APSs for old age. In Bolivia, where the non-contributory pension is universal, and virtually all men and women receive it, about 54.4 per cent of Renta Dignidad payments go to women, reflecting the larger proportion of women among the old due to higher life expectancy. Since both the PBS and Renta Dignidad are flat-rate (and not related to past earnings), women and men receive the same amount. In contrast, Solidarity Pensions in Bolivia remain limited in number and concentrated among men, probably because most women do not even meet the minimum contributory requirement for these benefits (ten years). ${ }^{16}$

Another gender relevant measure in both countries was the introduction of child credits to improve women's future pensions and to recognise and reward the unpaid work 
women perform in childcare (Arza, 2012c). In Chile, the child bonus (bono por hijo) is a non-means-tested right for all mothers retiring after July 2009. It is calculated on the basis of the equivalent of eighteen months of contributions at a monthly minimum wage plus an annual rate of return. In Bolivia, the child credit (aporte por hijo) recognises one year of contributions per child (up to a maximum of three children) in the calculation of the Solidarity Pension. Alternatively, women can use the child credit to retire sooner (also one year per child up to a maximum of three years). While these measures are positive, the gender gaps in contribution densities are far larger than what these credits can compensate for. In Chile, for instance, women spend almost half of their working lives (between ages eighteen and sixty) out of the labour market (Pension Commission, 2015: 67, Graph 6). Thus, in Chile, despite the expected positive impacts of the non-contributory benefits and the child credits to reduce gender gaps in coverage and increase the benefits of women, simulations also suggest that gender gaps in pension benefits will continue to exist (Fajnzylber, 2012: Table 13.4).

The Chilean reforms also entailed other, more specific gender-relevant measures (Carrera and Infante, 2012; Fajnzylber, 2012; Marco Navarro, 2012; Mesa-Lago and Ossio Bustillos, 2012; Yañez, 2010). These measures included compensation for the death and disability insurance premium paid by women, the possibility of pension sharing after divorce as determined by the judge, an option for voluntary affiliation on the part of unpaid workers, the possibility for women to leave survivorship benefits to their husbands (which was not possible in the previous system unless the man was disabled $)^{17}$ and the elimination of fixed administrative fees on individual accounts (Fajnzylber, 2012; Yañez, 2010, Arza, 2012c). One thing the Chilean reform of 2008 did not do was to make the use of unisex life expectancy mandatory for the calculation of benefits from individual accounts. The new Pension Commission's report, just released, discusses the impact that the use of sex-differentiated mortality tables has on the gender gap in benefits, and recommends their elimination (Pension Commission, 2015: 132, 79). ${ }^{18}$

One of the key limitations in both countries is that non-contributory pensions remain too low. In Chile, this was recognised in the new Pension Commission's report, which recommended a 20 per cent increase in the PBS, as well as the expansion of eligibility to include all, except the top 20 per cent higher income households. In Bolivia, the universal pension is even lower than the Chilean and below ECLAC's poverty line. Thus, older adults who have to rely only on those non-contributory benefits, mostly women, are clearly not adequately protected. In both countries, gender inequalities may have been mitigated with 're-reforms' and the expansion of non-contributory benefits, but they have not at all been overcome. In Chile, the issue came up once again to the policy agenda as a new reform process was opened to continue addressing this among other pending deficits of the current pension system.

\section{Discussion and conclusion}

Pension systems are often not well equipped to offer equal levels of old age protection for women and men in a context of gendered labour markets. In most countries, this generates gender inequalities in old age pension entitlements that reflect - and sometimes deepen - the gender inequalities that exist over the lifecourse. These gender gaps came to the policy agenda in recent Latin American pension reforms. Unlike the structural pension reforms of the 1980s and 1990s, which tended to privilege savings and to foster 
a strong link between contributions and benefits, recent policies have given a new role to redistributive components of the pension system, that can be particularly relevant for women.

The experiences of the four countries studied here show positive policy innovation. Women's access to pensions improved thanks to various types of measures that detached benefit rights from contribution histories, like non-contributory pensions. However, higher coverage rates are only the beginning of a much longer and needed path to gender equality in old age protection. Indeed, these country experiences also show the constraints that remain for gender equitable pension systems in the context of highly unequal labour markets and a gendered distribution of paid and unpaid work in the family. Some of the key remaining issues relate to benefit adequacy (and gender gaps in benefits), to the gender distribution of paid and unpaid work and to the institutionalisation of rights to old age protection for all, particularly for people without a lifelong working history in the formal labour market.

The first issue is common to a number of countries that have recently created new non-contributory pensions. In Chile, for instance, coverage has improved by means of the PBS, but benefits remain low. As long as the only way to obtain a higher pension is through self-financed individual accounts - a system which reproduces inequalities - gender equality appears to be a fleeting goal beyond the minimum benefit floor. The experiences of Chile, Bolivia and other countries in Latin America also show that while benefits have been extended to many older adults who previously had no pensions, the amounts remain low. Thus, many continue to suffer economic vulnerability in old age despite now receiving a benefit. Some countries - like Brazil, where the minimum pension is equal to the monthly minimum wage - have done better in this respect.

The second unresolved issue regards a gendered labour market and an unequal distribution of paid and unpaid work between men and women. Although women's labour market participation has been increasing, women continue to participate less than men and provide most of the unpaid work in the household. Child credits, where they exist, provide some but limited compensation, and are insufficient for women who spend most of their lives out of the labour force or in the informal labour market. To be sure, equal levels of protection for men and women in old age are unlikely to be achieved unless further measures are taken to improve gender equality over the entire life and pension systems cannot do all the work alone. In Chile, for instance, 11 per cent of all women (and 14 per cent of those in the lowest income quintile) report they do not participate in the labour market due to family reasons (taking care of children, older adults or other relatives) - compared to only 0.6 per cent of men (Pension Commission, 2015: 71, Table 8).

A third remaining problem relates to the institutionalisation of benefits as social rights. Some policies that have had a positive impact on gender equality, such as the Pension Moratorium in Argentina, do not set solid pension rights for uncovered women and men retiring in the years to come. Other policies that involve tight means-testing or depend on budget allocations each year also fail to secure rights for all. Measures like this can increase access or benefits levels at one point in time but they are vulnerable to budget cuts or changes in political priorities. Countries like Brazil, Bolivia and Chile have made progress institutionalising basic pensions as social rights, but the challenge remains in several other Latin American countries. 
Overall, recent experiences show growing awareness of the importance of the gender dimension of pension systems. But they also indicate the substantial challenges and constraints that remain, and the need for further policies for gender equality. It is not sufficient to provide a very low basic pension, or credit a few years of contribution for childbirth for every mother: that is often not enough to guarantee old age security for most women. Redistribution is essential for the protection of older persons who are not reached by contributory pensions and for women in particular. Policies must aim to incorporate all women (not only paid workers or poorest women), which essentially requires a universal policy design, or at least a policy architecture leading to universality. The task obviously goes also beyond the pension system itself. It will not be sufficient to compensate for existing inequalities reforming pension rules that punish women, it is also necessary to take a broader approach to recognise women's difficulties to participate in the labour market (and contribute for a pension) when they have care responsibilities, as well as the more structural inequalities that emerge and consolidate over the working life and are often reproduced at older ages.

\section{Acknowledgements}

I am grateful for funding for research on non-contributory pensions and cash transfers in Latin America from CONICET and Agencia Nacional de Promoción Científica y Tecnológica, Programa de Innovación Tecnológica, contrato Préstamo BID, PICT 20112492. Parts of this article build on earlier work on pension reform and gender equality in Latin America done for UNRISD (see Arza, 2012c). Special thanks to two anonymous referees for their insightful comments on this article.

\section{Notes}

1 Women's higher life expectancy reduces women's pension benefits when sex-differentiated mortality tables are used (for Latin America, see Arenas de Mesa et al., 2006; Bertranou, 2001; Bertranou and Arenas de Mesa 2003; Dion, 2007).

2 The two sections that follow resume and update part of the analysis in Arza (2012c) for Argentina, Bolivia and Chile.

3 Contributing time pensions require thirty years of contributions for women and thirty-five years for men and no minimum retirement age. Pursuant Constitutional Amendment 20 (1998) an adjustment factor was implemented (Factor Previdênciario) to strengthen the association between benefit values, on the one hand, and the retirement age, the time contributed and the life expectancy, on the other. In order to mitigate the impacts of these measures on gender inequality, a unisex mortality table and a bonus of five years for women's contributing time were established (Rocha da Silva and Schwarzer, 2003: 86, 88).

4 Calculated based on issued benefits as of December 2013 (MPS, 2013: 162).

5 Calculated based on the mean value of issued benefits for old age and contributing time pensions together (aponsentadoria idade and aposentadoria tempo de contribuição) (MPS, 2013: 162-3).

6 Calculated based on granted benefits (benefícios concedidos) for old age, contributing time and derived pensions (aposentadoria idade, aposentadoria tempo de contribuição and pensões por morte) at one piso previdenciário on year 2013 (MPS, 2013). To this, social assistance pensions, which are also at the value of one monthly minimum wage, could be added.

7 Calculated based on Res. ANSES 449/2014 (monthly minimum pension) and MTEySS (2015) (monthly minimum wage).

8 Calculated based on data from MTEySS (2012: 24). 
9 Data corresponding to year 2013 for both Bolivia and Chile, from IDB (2015).

10 Decree 336 (2006), art. 2(e), own translation.

11 Law 065 (2010), art. 3(j), own translation.

12 Similar benefits were also created for the risk of disability.

13 All benefit values as of November 2015, calculated from Pension Commission (2015: 56).

14 Benefit value in US dollars as of November 2015, from APS (2015a). Value as per cent of poverty line corresponds to year 2011 (due to lack of more recent data) based on the urban poverty line per person from the Economic Commission for Latin America and the Caribbean (ECLAC) (taken from CEPAL (2013), Statistical Appendix, Table 6).

15 Benefit values from Law 430 (2013), in US dollars as of November 2015.

16 The gender distribution of Renta Dignidad was estimated based on the number of payments made over the period 2008-2015 for women and men. Data correspond to October 2015 in the case of the Solidarity Pension (Bolivia) and to November 2015 in the cases of Renta Dignidad (Bolivia), PBS and APS (Chile). Calculated from APS (2015a, 2015b) for Bolivia and Superintendencia de Pensiones (2015) for Chile.

17 This measure can have a mixed impact on gender equality. While it is positive in terms of gender parity, in a system of individual accounts it may also reduce women's pensions as funds may need to be reserved in case of widowhood (Fajnzylber, 2012).

18 At the time of writing, the Chilean reform process remains open and no reform has yet been enacted.

\section{References}

Alásia de Heredia, B. and Pezza Cintrão, R. (2006) 'Gênero e acesso a políticas públicas no meio rural brasileiro', in UNIFEM (ed.), O Progresso das Mulheres no Brasil, Brasilia: UNIFEM/Ford Foundation/CEPIA, 102-31.

ANSES (2011) Análisis de la cobertura previsional del SIPA: Protección, inclusión e igualdad, Buenos Aires: Administración Nacional de la Seguridad Social.

Antía, F. and Provasi Lanzara, A. (2011) 'Multi-pillared social insurance systems: the post-reform picture in Chile, Uruguay and Brazil', International Social Security Review, 61, 1, 53-71.

APS (2015a) Estadisticas de la Renta Dignidad, Autoridad de Fiscalización y Control de Pensiones y Seguros del Estado Plurinacional de Bolivia, http://www.aps.gob.bo/estadisticas/Paginas/Renta-Dignidad.aspx (accessed December 2015).

APS (2015b) Prestaciones y beneficios de la seguridad social de largo plazo, Autoridad de Fiscalización y Control de Pensiones y Seguros del Estado Plurinacional de Bolivia, http://www.aps.gob.bo/estadisticas/ (accessed December 2015).

Arenas de Mesa, A. (2010) Historia de la reforma previsional en Chile: Una experiencia exitosa de política pública en democracia, Santiago: Oficina Internacional del Trabajo.

Arenas de Mesa, A. and Gana Cornejo, P. (2003) 'Protección social, pensiones y género en Chile', in F. Bertranou and A. Arenas de Mesa (eds.), Protección social, pensiones y género en Argentina, Brasil y Chile, Santiago: Oficina Internacional del Trabajo.

Arenas de Mesa, A., Llanes, M. C. and Miranda Bravo, F. (2006) 'Protección social efectiva, calidad de la cobertura, efectos distributivos del sistema de pensiones en Chile', Serie Financiamiento y Desarrollo 178, Santiago: CEPAL.

Arza, C. (2008) 'The limits of pension privatization: lessons from the Argentine experience', World Development, 36, 12, 2696-712.

Arza, C. (2012a) 'Policy change in turbulent times: the nationalization of pension funds in Argentina', in P. Utting, S. Razavi and R. Buchholz (eds.), The Global Crisis and Transformative Social Change, London: Palgrave Macmillan.

Arza, C. (2012b) 'Extending coverage under the Argentinean pension system: distribution of access and prospects for universal coverage', International Social Security Review, 65, 5, 29-49. 
Arza, C. (2012c) Pension Reforms and Gender Equality in Latin America, Gender and Development Programme Paper 15, Geneva: UNRISD.

Arza, C. (2015) The Gender Dimensions of Pension Systems: Policies and Constraints for the Protection of Women, Discussion Paper 1, New York: UN-Women.

Barrientos, A. (1998) Pension Reform in Latin America, Aldershot: Ashgate.

Beltrão, K. I., Sugahara Pinheiro, S., Paes Leme Peyneau, F. and Oliveira Mendoça, J. L. (2005) 'The 1988 Constitution and access to social security in rural Brazil: towards universalization', in A. A. Camarano (ed.), Sixty Plus: The Elderly Brazilians and Their New Social Roles, Río de Janeiro: IPEA, 317-48.

Berstein, S., Castañeda, P., Fajnzylber, E. and Reyes, G. (2009) Chile 2008: Una reforma previsional de segunda generación, Santiago: Superintendencia de Pensiones.

Bertranou, F. (2001) 'Pension reform and gender gaps in Latin America: what are the policy options?', World Development, 29, 5, 911-23.

Bertranou, F. and Arenas de Mesa, A. (2003) Protección social, pensiones y género en Argentina, Brasil y Chile, Santiago: Oficina Internacional del Trabajo.

Bertranou, F., Cetrángolo, O., Grushka, C. and Casanova, L. (2011) Encrucijadas en la seguridad social argentina: reformas, cobertura y desafíos para el sistema de pensiones, Buenos Aires: CEPAL y Oficina Internacional del Trabajo.

Bolivia, Estado Plurinacional de (2010) Law 065, Ley de Pensiones, 10 December 2010.

Bolivia, Estado Plurinacional de (2013) Law 430, Modificación de la Ley de Pensiones, 7 November 2013.

Bonadona Cossío, A. (2003) 'Género y sistemas de pensiones en Bolivia', Serie Mujer y Desarrollo 44: CEPAL.

Brooks, S. (2009) Social Protection and the Market in Latin America: The Transformation of Social Security Institutions, New York: Cambridge University Press.

Calvo, E., Bertranou, F. and Bertranou, E. (2010) 'Are old-age pension system reforms moving away from individual retirement accounts in Latin America?', Journal of Social Policy, 39, 2, 223-34.

Carrera, C. and Infante, M. (2012) 'Análisis de la implementación de políticas públicas y la relación con los indicadores del Observatorio de igualdad de género de América Latina y el Caribe: El caso de Chile', in K. Batthyány Dighiero and S. Montaño Virreira (eds.), Construyendo autonomía. Compromisos e indicadores de género, Santiago de Chile: Comisión Económica para América Latina y el Caribe (CEPAL), Ministerio de Asuntos Exteriores y de Cooperación.

CEPAL (2013) 'Social Panorama of Latin America', Santiago de Chile: CEPAL.

Délano, D. (2010) Reforma previsional en Chile: Protección social para todos, Santiago de Chile: Oficina Internacional del Trabajo.

Dion, M. (2007) 'Pension reform and gender inequality', in S. Kay and T. Sinha (eds.), Lessons from Pension Reform in the Americas, Oxford: Oxford University Press, 134-63.

Fagnani, E. and Tonelli Vaz, F. (2013) 'Seguridade social, direitos constitucionais e desenvolvimento', in A. Fonseca and E. Fagnani (eds.), Políticas sociais, desenvolvimento e cidadania. Educação, seguridade social, pobreza, infraestrutura urbana e transição demográfica, Volume 2, São Paulo: Editora Fundação Perseu Abramo, 93-115.

Fajnzylber, E. (2012) 'Gender policy and pensions in Chile', in R. Holzmann, E. Palmer and D. Robalino (eds.), Nonfinancial Defined Contribution Pension Schemes in a Changing Pension World, Volume 2: Gender, Politics, and Financial Stability, Washington, DC: World Bank, 113-38.

Fajnzylber, E. and Paraje, G. (2013) 'Chile', in R. Rofman, I. Apella and E. Vezza (eds.), Más allá de las pensiones contributivas: Catorce experiencias en América Latina, Buenos Aires: Banco Mundial, 159-98.

Frericks, P. and Maier, R. (2008) 'The gender pension gap: effects of norms and reform policies', in C. Arza and M. Kohli (eds.), Pension Reform in Europe: Politics, Policies and Outcomes, Abingdon: Routledge, 175-95.

Gilbert, N. (2006) Gender and Social Security Reform, New Jersey: Transaction Publisher.

Ginn, J. (2008) Gender, Pensions and the Lifecourse: How Pensions Need to Adapt to Changing Family Forms, Bristol: The Policy Press. 
Goldberg, L. and Lo Vuolo, R. M. (2006) Falsas promesas: Sistema de previsión social y régimen de acumulación, Buenos Aires: Miño y Dávila, Centro Interdisciplinario para el Estudio de Políticas Públicas.

Groisman, F. and Sconfienza, M.E. (2013) 'El servicio doméstico en Argentina. Particularidades y desafíos de un sector relegado', Carta Económica Regional, 25, 111-12, 151-72.

Hohnerlein, E.-M. (2012) 'Pension re-reform in Argentina', ZIAS, 3, 26, 213-33.

IDB (2015) Sociometro Bid (database), Inter-American Development Bank, http://www.iadb.org/ research/sociometroBID/charts.cfm?lang=en\&indicator=5 (accessed November 2015).

Kay, S. J. (2013) 'Political risk and the reversal of pension reform', paper presented at Latin American Studies Association Annual Congress, Washington DC.

Kritzer, B. E., Kay, S. J. and Sinha, T. (2011) 'Next generation of individual account pension reforms in Latin America', Social Security Bulletin, 71, 1, 35-76.

Laserna, R. (2013) 'Bolivia', in R. Rofman, I. Apella and E. Vezza (eds.), Más allá de las pensiones contributivas: Catorce experiencias en América Latina, Buenos Aires: Banco Mundial, 91-118.

Lavinas, L. (2012) 'Brasil, de la reducción de la pobreza al compromiso de erradicar la miseria', Revista CIDOB d'afers internacionals, 97-98, 67-86.

Madrid, R. (2003) Retiring the State: The Politics of Pension Privatization in Latin America and Beyond, Standford, CA: Standford University Press.

Marco Navarro, F. (2012) 'Autonomía económica en la vejez: La reforma previsional y el uso de indicadores de género en Bolivia (Estado Plurinacional de)', in K. Batthyány Dighiero and S. Montaño (eds.), Construyendo autonomía. Compromisos e indicadores de género, Santiago de Chile: CEPAL, 161218.

Marco Navarro, F. (2004) Los sistemas de pensiones en América Latina: Un análisis de género, Santiago de Chile: CEPAL.

Matijascic, M. and Kay, S.J. (2014) 'The Brazilian pension model: the pending agenda', International Social Security Review, 67, 1, 71-93.

Mesa-Lago, C. (2004) 'An appraisal of a quarter-century of structural pension reforms in Latin America', Cepal Review, 84, 57-81.

Mesa-Lago, C. (2006) 'Structural pension reform - privatization - in Latin America', in G. Clark, A. Munnell and M. Orszag (eds.), The Oxford Handbook of Pensions and Retirement Income, Oxford and New York: Oxford University Press, 663-83.

Mesa-Lago, C. (2009) 'Re-reform of Latin American private pensions systems: Argentinian and Chilean models and lessons', The Geneva Papers on Risk and Insurance, 34, 602-17.

Mesa-Lago, C. (2012) 'Pension re-reform in Chile', ZIAS, 3, 26, 197-211.

Mesa-Lago, C. and Ossio Bustillos, L. (2012) 'Pension re-reform in Bolivia', ZIAS, 3, 26, $235-57$.

Molina, F. (2006) 'Biografía del Bonosol', in Fundación Milenio (ed.), La inversión prudente. Impacto del Bonosol sobre la familia, la equidad social y el crecimiento económico, La Paz: Fundación Milenio.

MPS (2013). Anuário Estatístico da Previdência Social, Brasilia: Ministêrio da Previdência Social.

MPS (2015) Informe da Previdência Social, 27, 4, Brasilia: Ministério da Previdência Social.

MTEySS (2012) 'Boletín estadístico de la seguridad social. Segundo trimestre', Buenos Aires: Ministerio de Trabajo, Empleo y Seguridad Social.

MTEySS (2015) Boletín de Estadísticas Laborales, http://www.trabajo.gov.ar (accessed June 2015).

Müller, K. (2009) 'Contested universalism: from Bonosol to Renta Dignidad in Bolivia', International Journal of Social Welfare, 18, 2, 163-72.

Pension Commission (2015) Informe Final, Comisión Asesora Presidencial sobre el Sistema de Pensiones, Santiago de Chile, disponible en http://www.comision-pensiones.cl/ (accessed November 2015).

Rocha da Silva, E. and Schwarzer, H. (2003) 'Protección social, jubilaciones, pensiones y género en Brasil', in F. Bertranou and A. Arenas de Mesa (eds.), Protección social, pensiones y género en Argentina, Brasil y Chile, Santiago: Oficina Internacional del Trabajo, 65-136. 
Rofman, R. (2013) 'Argentina', in R. Rofman, I. Apella and E. Vezza (eds.), Más allá de las pensiones contributivas. Catorce experiencias en América Latina, Buenos Aires: Banco Mundial, 61-90.

Rofman, R. and Grushka, C. (2003) 'Protección social, jubilaciones, pensiones y género en Argentina', in F. Bertranou and A. Arenas de Mesa (eds.), Protección social, pensiones y género en Argentina, Brasil y Chile, Santiago: Oficina Internacional del Trabajo

Schwarzer, H. and Ferreira de Santana, R. L. (2013) 'Brasil', in R. Rofman, I. Apella and E. Vezza (eds.), Más allá de las pensiones contributivas. Catorce experiencias en América Latina, Buenos Aires: Banco Mundial, 119-58.

Superintendencia de Pensiones (2015) Centro de Estadísticas de la Superintendencia de Pensiones de Chile, http://www.spensiones.cl/safpstats/stats/ (accessed December 2015).

Willmore, L. (2006) 'Non-contributory pensions: Bolivia and Antigua in an international context', Serie Financiamiento del Desarrollo 167, Santiago de Chile: Comisión Económica para América Latina y el Caribe.

Yañez, S. (2010) 'La dimensión de género en la reforma previsional chilena (Ley No. 20.255 de reforma de pensiones)', Serie Mujer y Desarrollo 101, Santiago: CEPAL. 